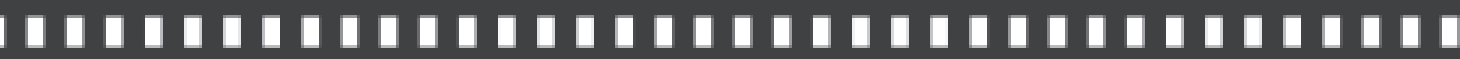 Estratégias de producção de sentidos: uma reflexão sobre a comicidade e a metáfora na ilustração fotográfica ס
}

Ana Carolina Lima Santos 


\title{
Estratégias de produção de sentidos: uma reflexão sobre a comicidade e a metáfora na ilustração fotográfica
}

\author{
Strategies for production of meaning: \\ a reflection on the comic and metaphor in photographic illustration
}

Ana Carolina Lima Santos *

\begin{abstract}
Resumo: O presente trabalho tenta conceber os modos de produção de sentidos da foto-ilustração, dando especial atenção à comicidade e à metáfora. As ideias de um efeito cômico e de um caráter metafórico dessas imagens são trabalhadas a fim de serem entendidas numa dupla função: de um lado, estabelecendo uma relação de cumplicidade com o leitor e, de outro, servindo enquanto operador cognitivo. Assim, elas funcionam para um fim retórico, pois se configuram como procedimentos para a construção de uma mensagem que visa guiar o leitor na interpretação dos assuntos noticiados.
\end{abstract}

Palavras-chave: foto-ilustração; comicidade; metáfora; jornalismo de revista.

\begin{abstract}
This paper attempts to design the forms through which photo-illustrations are able to make sense, with special attention to comedy and metaphor. The ideas of a comic effect and a metaphorical character of these images are worked in order to understand them in a dual role: on one hand, establishing a relationship of complicity with the reader and, on the other, serving as a cognitive operator. Thus, they work for a rhetorical purpose, because they are configured as procedures for the construction of a message that is aimed at guiding the reader in interpreting the issues reported.
\end{abstract}

Key-words: photo-illustration; comedy, metaphor; magazine journalism.

\footnotetext{
*Doutoranda do Programa de Pós-Graduação em Comunicação Social da Universidade Federal de Minas Gerais. Mestre em Comunicação e Cultura Contemporâneas pela Universidade Federal da Bahia. Graduada em Comunicação Social - Bacharel em Jornalismo pela Universidade Federal de Sergipe. E-mail: outracarol@gmail.com.
} 


\section{Introdução}

A ilustração fotográfica é um tipo de fotografia comumente encontrado na imprensa, que não se configura como um "recorte do real", sendo, ao contrário, produzido em estúdio e/ou posteriormente montado e manipulado para acompanhar as matérias jornalísticas. (SOUSA, 2004).

Efetivamente, por não ser uma simples implicação existencial de uma realidade exterior e nem buscar um ajustamento com essa dimensão factual, a foto-ilustração não pode ser pensada a partir das balizas de uma experiência de mundo emprestada, de caráter apresentativo e descritivo-como normalmente se conceitua as fotografias jornalísticas. Para além da apresentação ou da descrição, a ilustração fotográfica é melhor explicada quando concebida como a materialização visual de um conceito por meio do qual o tema noticiado se torna compreensível segundo uma posição ou ponto de vista defendido na reportagem que acompanha.

Assim, ao ser posicionada em uma determinada matéria jornalística, a foto-ilustração funciona como um modo de ilustrar visualmente aquilo que é exposto no texto; esclarecendo, elucidando ou comentando as ideias desenvolvidas verbalmente. '[...] Chamamo-las 'ilustrativas' por atender os requisitos fundamentais dessa função: auxiliar a melhor compreensão de um objeto, idéia ou conceito estabelecido de antemão."1 (BAEZA, 2001, p.166). A ilustração fotográfica serve, pois, a uma finalidade explicativa, por vezes analítica ou opinativa - que, em conjunto com o texto, funciona como uma interpretação ou argumentação acerca do real.

Nesse sentido, a foto-ilustração estabelece com o regime da informação uma relação diferente daquela tradicionalmente instituída pelo fotojornalismo: ela está menos ligada a uma função informacional de apresentação dos acontecimentos do que a uma possibilidade de explicá-

\footnotetext{
${ }^{1}$ Tradução livre da autora.
} 
los, sedimentando análises, juízos e opiniões acerca dos fatos noticiados, fazendo da imagem apenas um meio para criar uma "nova realidade" que, ficcional ${ }^{2}$, se refere ao mundo real na medida em que serve como exemplificação de um determinado conceito que ajuda a elucidá-la.

Dessa forma, entendida como ficção e como manipulável, a ilustração fotográfica não mais fundamenta a sua credibilidade na noção de ser uma representação fiel do mundo. Ao contrário, os indivíduos acreditam nela ao passo em que parece fazer sentido, isto é, ao passo em que a informação que municia for condizente com a compreensão que estes sujeitos têm do mundo (KELLY; NACE apud SOUSA, 2000)-e que, nesse caso, é posta diante dos olhos.

Para isso, a ilustração fotográfica é normalmente construída a partir de estratégias que a permitam estabelecer uma relação de cumplicidade ou simpatia com o leitor, a partir da qual a foto-ilustração se autoriza a "falar com o seu público". Essa cumplicidade que lhe é atribuída repercute uma característica do jornalismo levado a cabo pelas revistas de informação; mídia a qual se associa esse tipo fotográfico. Em tais veículos, o laço que se estabelece com os leitores é da ordem de uma partilha de identidades ${ }^{3}$, no sentido de que a revista se dirige a um público que julga pertencer ao seu grupo e compartilhar das mesmas visões de mundo. (SCALZO, 2004).

No caso da foto-ilustração, para serem verdadeiramente aceitos pelo receptor, os sentidos por ela veiculados precisam de alguma forma ecoar uma visão de mundo possível do leitor, reafirmando-a. Em tal sentido, essa imagem funciona melhor se há, a priori, o estabelecimento de um vínculo entre emissor-receptor.

\footnotetext{
${ }^{2}$ Por ficcional, refere-se aqui às fotografias que se distanciam do "isso-foi" barthesiano, ou seja, que não se apresentam como sendo o real no estado passado (BARTHES, 1998, p.124).

${ }^{3}$ Embora a produção e a aceitação de sentidos estejam, nesse caso, dependentes de um vínculo de identidades; jornalisticamente, essa relação é justificada com a noção de "contrato de leitura", segundo o qual o jornalista pode garantir a adesão de seus interlocutores ao tipo de jogo comunicativo que propõe. Nesse sentido, talvez mais importante do que compartilhar identidades seja constituir uma compatibilidade entre as intencionalidades do comunicador e os reconhecimentos de tais intenções da parte do receptor. É exatamente a partir dos paralelos estabelecidos entre esses dois polos que os sentidos da comunicação podem ser construídos e legitimados. (MOTTA, 2003).
} 
É exatamente a tal função que serve duas importantes estratégias, a comicidade e da metáfora; aqui como estratégias de aproximação com o leitor: em um caso, instalando um tom de gracejo e, no outro, de familiaridade.

Dessa maneira, a comicidade e a metáfora colaboram para uma aceitação dos sentidos transmitidos a partir da ilustração fotográfica na medida em que estabelece uma aproximação entre emissor e receptor. É, portanto, um procedimento tácito semelhante àquele já identificado por Marcia Benetti no que diz respeito ao emprego da ironia como estratégia discursiva da revista Veja (inclusive no que diz respeito a fotografias). A autora chama atenção para o fato de que a ironia enquanto recurso jornalístico é abalizada, em termos de recepção, em um processo de reconhecimento e compartilhamento de saberes.

\begin{abstract}
A força da ironia está sempre na construção de um campo de cumplicidade entre os sujeitos. No caso do jornalismo, entre jornalista e leitor. A lógica intersubjetiva que se estabelece coloca estes dois sujeitos em estado de mútuo reconhecimento. De forma aqui bastante redutora, seria algo como 'somos semelhantes'. Eu, jornalista, me expresso de um modo determinado e você, leitor, é capaz de me compreender; nem todos seriam capazes de me compreender, mas você é meu parceiro. Eu, leitor, tenho as mesmas referências de mundo que você, jornalista; nem todos utilizam os mesmos mapas de significado, mas nós utilizamos os mesmos mapas e por isso somos parceiros. (BENETTI, 2007, p.6-7).
\end{abstract}

Bem como no caso da ironia, a foto-ilustração depende dessa cumplicidade para funcionar como representação. Sem ela, a imagem corre o risco não apenas de ser incompreendida, mas, além disso, de ser reconhecida como uma linguagem não autorizada à transmissão de informações jornalisticamente pertinentes. Nesse sentido, a cumplicidade se torna essencial; do contrário, as extrapolações analíticas e opinativas correm o risco de serem consideradas como excedentes da atividade jornalística, uma vez que não respaldada pelo ideal, ainda que ilusório, de objetividade jornalística. 
Assim, é através dessas estratégias da comicidade e da metáfora como uma forma de aproximação e de uma decorrente cumplicidade com o leitor que a ilustração fotográfica é capaz de viabilizar ideias e conceitos que podem ser tomados como "evidentes" e "verdadeiros" e, em consequência, válidos como recursos utilizáveis no âmbito jornalístico.

Entretanto, para além desse papel, a comicidade e a metáfora das ilustrações fotográficas devem ser percebidas como modos de construção de sentidos que possibilitam instaurar ou figurar plasticamente as ideias que são arquitetadas na foto-ilustração, sempre com objetivos retóricos.

\section{O efeito cômico}

Um dos traços recorrentes enquanto estratégia de produção de sentido da foto-ilustração diz respeito ao teor humorístico que emerge com essas imagens. É possível perceber que a maior parte das ilustrações fotográficas busca, senão o riso, uma certa graça - sentimento cômico por excelência. (GOMES, 2004). O riso, o sorriso, o divertimento são entendidos, pois, como manifestações possíveis de um efeito cômico que parece ser pretendido por essas fotografias.

De um modo geral, os fenômenos humorísticos dessa natureza foram (e ainda são) objetos de estudos de inúmeros psicólogos, linguistas, filósofos, estetas e críticos de arte. Por conta disso, essa temática é marcada por uma heterogeneidade de aportes conceituais chamados em causa para a sua compreensão. Dentre as teorias que surgem nesse contexto, uma delas parece ser mais apropriada ao caso da ilustração fotográfica: a teoria da incongruência ${ }^{4}$.

\footnotetext{
${ }^{4}$ A teoria da hostilidade (o humor como zombaria) e a teoria da libertação (humor como forma de escape) também podem ser úteis ao entendimento da comicidade própria à foto-ilustração tanto que o viés de zombaria será discutido em seguida. Entretanto, para uma aproximação inicial, a teoria da incongruência funciona melhor, posto que busca apontar a essência do fenômeno e não suas causas ou efeitos, como fazem, respectivamente, as teorias da hostilidade e da libertação.
} 
Aristóteles, James Beattie, Immanuel Kant, Arthur Schopenhauer, Henri Bergson e Paul McGhee são alguns dos autores que, a despeito das diferenças que os separam, contribuíram de alguma forma para o desenvolvimento dessa teoria. A ideia da existência de contrastes entre um sentido esperado e o sentido efetivamente encontrado (um sentido incongruente e aparentemente deslocado) é o elemento que une esses teóricos em torno da teoria da incongruência. (ERMIDA, 2002).

Nesse sentido, segundo tal concepção, o humor se dá quando elementos díspares são coordenados de tal forma que resultam não em uma desorganização ou incoerência completas, mas, sim, num efeito de surpresa.

Quando achamos graça a algo que ouvimos ou observamos, é porque a súbita percepção de uma incongruência nos obriga a refazer uma interpretação inicial errada e chegar a um sentido surpreendente que não supuséramos à partida. Daí que a noção de jogo seja freqüentemente associada a este processo de contínuo recomeço. (ERMIDA, 2002, p.X).

Ao analisar pequenas historietas cômicas, Violette Morin aponta exatamente a conjunção de elementos aparentemente inconciliáveis como principal estratégia da construção do humor. Conforme o exame por ela efetuado, o humor é sempre deflagrado a partir de um disjuntor, isto é, de um elemento polissêmico concreto sobre o qual a história "tropeça" e se volta para seguir um novo rumo, subvertendo o percurso de leitura, anulando as expectativas anteriormente levantadas e dando a ela inesperadas direções. (MORIN, 1973).

Pensando a foto-ilustração nesses termos, o humor nela observado quase sempre passa pela combinação, numa mesma imagem, de elementos díspares. Com isso, leva-se a cabo uma contradição de expectativas que faz com que a sua interpretação oscile entre os sentidos possíveis e o sentido real, somente a partir do qual se dissolve a inconsistência da representação que é percebida no primeiro momento.

Para além desse mecanismo macroestrutural que permite inventariar o cômico como gênero textual, o humor gráfico, no qual se insere a 
ilustração fotográfica, se baseia em modos específicos. Existem, pois, algumas características comuns às diferentes formas de humor gráfico, como a exageração, a justaposição não usual e as relações irônicas. Além delas, a graça visual pode ser alcançada por meio da repetição, da distorção e de outras espécies de transformação e interferência da imagem. (HELLER, 2002).

Longe de serem exclusivos a esse tipo, tais recursos configuram-se tão somente como ferramentas passíveis de construir plasticamente uma intenção humorística-mesmo porque esses recursos também podem ser aplicados ao design "sério". Nessa perspectiva, o que vai determinar efetivamente a comicidade é o mecanismo macroestrutural da incongruência ou do paradoxo.

Assim, embora não dialoguem diretamente com as conjecturas de Morin, essas ideias aproximam-se delas: as categorias pensadas pela autora encontram paralelos nessas estratégias de humor gráfico. Isso porque, é ao fazer uso de tais mecanismos, que a imagem consegue chegar a um sentido de incoerência ou incongruência que permite a bifurcação interpretativa idealizada por Morin.

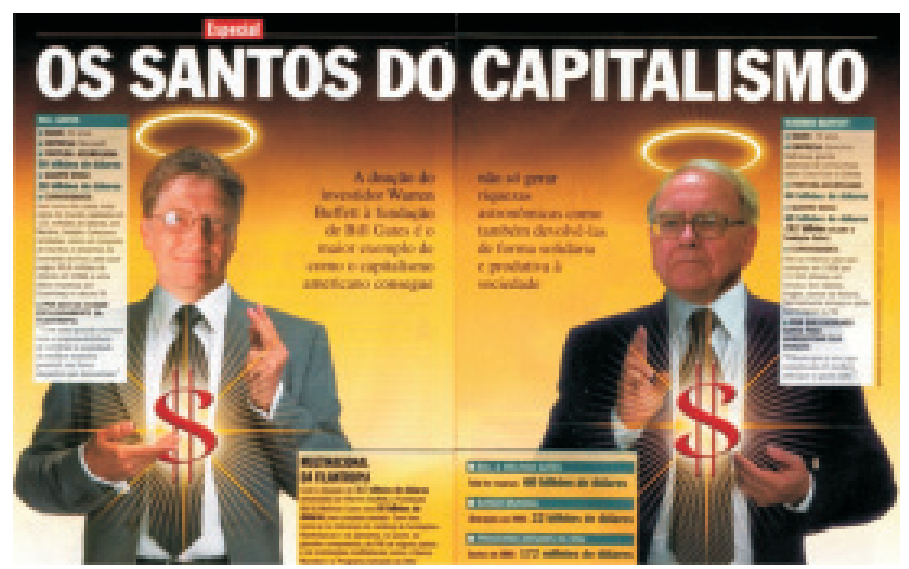

Figura 1 - Montagem da revista Veja

Fotografia: Pedro Rubens, Randall Scott e Nancy Karzerman

Fonte: Veja de 5 de julho de 2006, p.60-61 
É o caso da ilustração fotográfica "Os santos do capitalismo" (Figura 1). Nela se vê, dispostos lado a lado, dois homens, devidamente identificados como sendo Bill Gates e Warren Buffett, importantes empresários norte-americanos. No entanto, embora tenha como elemento básico de constituição fotografias dos dois indivíduos, a imagem é construída por meio de uma montagem.

Em primeiro lugar, os rostos estão dispostos sobre corpos que provavelmente não pertencem a esses homens. Eles, incorporando um sistema de gestualidade principalmente a partir do posicionamento das mãos, ligam prontamente a imagem a esquemas de representações religiosas. Além disso, as auréolas acima das cabeças e o feixe de luz que emana dos troncos reafirmam essa associação. A interpretação da ilustração fotográfica vincula-se, então, a hábitos perceptivos decorrente do modo que figuras santificadas são tradicionalmente representadas. Com isso, Gates e Buffett são tomados como santos.

Contudo, ao contrário do que se pode fazer crer num primeiro olhar, o sentido da imagem tropeça em um disjuntor. Ao invés do coração, símbolo do amor e da espiritualidade, o que deles emana luz é um cifrão, sinal utilizado para expressar dinheiro e riqueza normalmente pouco associados a valores cristãos. Assim, através do sentido de ambiguidade que é causado pela combinação de elementos díspares, um novo significado toma forma. Insinuando o inverso do que aparenta a princípio, isto é, de que eles não são exatamente santos, um certo efeito humorístico se instaura pela justaposição não usual e pela relação irônica daí derivada.

A mesma contradição perpassa também os elementos verbais. No título, associando duas palavras supostamente incompatíveis, brinca-se com a incongruência entre santidade e capitalismo. Entretanto, parece encerrar-se aí o tom irônico da matéria. O subtítulo ("A doação do investidor Warren Buffett à fundação de Bill Gates é o maior exemplo de como o capitalismo americano consegue não só gerar riquezas astronômicas, como também devolvê-las de forma solidária e produtiva à sociedade") já é desprovido dele. 
Nesse sentido, é possível notar que, embora continue insistindo na combinação de elementos díspares, o texto não se baseia no humor. Isso porque, ao contrário do que acontece na imagem, ele não estabelece o elemento fantasioso ou lúdico tido como pré-requisito para o efeito cômico - somente a partir do qual se possibilita a percepção da incongruência como algo impossível e, portanto, dotado de graça. (MCGHEE apud ERMIDA, 2008).

Assim sendo, o texto liga-se a essa foto-ilustração muito mais para explicar e resolver a própria inconsistência anteriormente colocada. Dessa maneira, restabelecendo o nexo da representação, supera-se o efeito cômico então criado, transmutando-o em meio cujo fim é a sátira. A comicidade passa, portanto, a servir ao objetivo de apontar, criticar e censurar os defeitos, erros e vícios de determinado caráter ou situação.

Essa dimensão de "arma" a que serve o humor já tinha sido concebida, pelo menos, desde Vladimir Propp. Em Comicidade e riso, ao abalizar a zombaria como o único aspecto permanentemente ligado à esfera do cômico, o autor afirma que o riso (considerado por ele a correlação imediata à comicidade) se dá quando da manifestação de defeitos antes imperceptíveis. Nesse sentido, desvelando uma fragilidade ou inconsistência do fenômeno representado através do humor, chama-se atenção para a existência desses aspectos negativos, a partir das quais se "cria ou reforça a reação de condenação, de inadmissibilidade, de não compactuação" (PROPP, 1992, p.211) com aquilo que é exposto.

É exatamente essa a dinâmica de funcionamento da caricatura: tomando e dimensionando defeitos sutis, ela amplia-os a ponto de tornálos visíveis e, portanto, julgáveis por todos. Por meio do exagero de um detalhe específico que nela toma proporções gigantescas, apagando os demais elementos constitutivos do que é posto à caricaturização, distorce-se deliberadamente a imagem de pessoas e circunstâncias. No entanto, essa exageração só toma um viés humorístico ao fazer parecer que o excesso levado a cabo não é o objetivo, mas apenas 
um meio para tornar manifestos características que já existem de antemão. (BERGSON, 1983).

Assim, entendida como um trocadilho visual nos quais as deformações operadas ao nível da aspectualidade promovem o conhecimento de uma verdade que de outra maneira não poderia ser visualmente apreendida (KRIS; GOMBRICH, 1938), a caricatura traça, através do paralelo da aparência, uma afinidade entre representação e realidade que vai para além das exterioridades. Mais do que a obtenção de um caráter real, busca-se mostrar na imagem traços que permitam entendê-la como equivalências metafóricas de estados efetivos.

Todas as descobertas artísticas são descobertas não de semelhanças, mas de equivalências que nos permitem ver a realidade em termos de uma imagem e uma imagem em termos de realidade. E essa equivalência não repousa tanto na semelhança dos elementos, como na identidade de reações a certos parentescos. Reagimos a um borrão branco na silhueta negra de um jarro como se fosse um ponto de luz. Reagimos à pêra com suas linhas entrecruzadas como se fosse a cabeça do Rei Luiz Felipe. (GOMBRICH, 2007, p.292).

O mesmo pode ser verificado em algumas ilustrações fotográficas. Ao tentar, através do procedimento de deformação, assinalar um sentido segundo, elas operam num terreno próximo ao da caricatura. A imagem "Dirceu, o ex-mestre dos disfarces" (Figura 2) é um exemplo disso. Preenchendo mais da metade da segunda página da matéria, a ilustração fotográfica retrata o político José Dirceu com uma estranha aparência seu rosto é de tal forma deformado que, ao funcionar como disjuntor da representação, leva o espectador a associá-lo ao Pinóquio, o boneco mentiroso. 


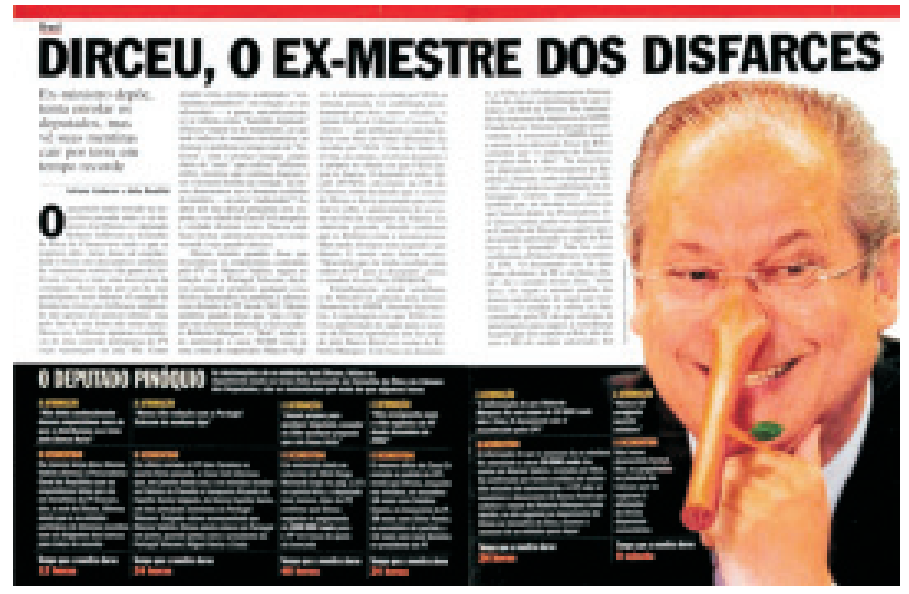

Figura 2 - Montagem da revista Veja Fotografia: Dida Sampaio

Fonte: Veja de 10 de agosto de 2005, p.70-71

A foto-ilustração tem como elemento básico de constituição uma fotografia de José Dirceu. Contudo, a imagem não se apresenta do mesmo modo como foi originalmente fotografada. Submetida a manipulações digitais, a partir das quais algumas de suas propriedades são deformadas, a imagem é revestida por uma "máscara". Embora não se perca todas as características apreendidas pela fotografia original, uma nova configuração é dada: o rosto do político apresenta-se agora revestido por uma textura desumanizada que remete a um pedaço de madeira, no qual um galho se sobressai no lugar do seu nariz.

Essa reconfiguração parece ter sido intencionalmente construída para acionar no receptor uma bagagem cultural que associa a representação do ex-ministro à fabula do Pinóquio. Publicado originalmente em 1883 pelo italiano Carlo Lorenzini, sob o pseudônimo de Carlo Collodi, tal narrativa alegórica descreve as aventuras de um boneco de madeira que queria ser um garoto de verdade. Na história original, o boneco, sem preocupar-se com o que é certo ou errado, mas apenas procurando sua satisfação imediata, se envolve em inúmeras confusões. Para sair-se delas, ele mente. Toda vez que mente, seu nariz cresce um pouco. 
Retratando Dirceu com um nariz de madeira crescido, tal qual o Pinóquio, a ilustração fotográfica induz a uma interpretação que pressupõe que o deputado, para estar assim, deve ter contado muitas mentiras. Dessa maneira, a representação não sugere a literalidade de que ele seja um boneco de madeira, mas aproxima-o do tipo de atitude que caracteriza o boneco da fábula. O efeito alcançado diz respeito à atribuição ao político da falta de compromisso com qualquer princípio, da ausência de dever e moral e da inexistência de ética que o boneco da fábula conota.

Além disso, outros elementos da fotografia funcionam para o mesmo fim. O olhar furtivo, a sobrancelha arqueada e o sorriso malicioso dão a ele um ar de leviandade que acaba por reforçar o sentido da aproximação entre o caráter de Dirceu e o de Pinóquio. A coerência entre o efeito comparativo e essas unidades visuais da imagem faz com que a ilustração fotográfica obtenha um resultado que se apresenta integrado e harmonioso.

Se a informação arquitetada visualmente refere-se a uma interpretação que atribui a Dirceu determinados predicativos, o texto verbal também trabalha no intento de atingir resultados semelhantes, reforçando a ideia transmitida pela foto-ilustração e sendo por ela reforçado. O primeiro elemento de destaque do registro verbal é o título, que cumpre o papel de explicitar o assunto da matéria. "Dirceu, o ex-mestre dos disfarces" comunica, de antemão, a noção de que a reportagem trata de algum fato capaz de desmascarar o deputado. O subtítulo especifica: "Exministro depõe [no Conselho de Ética da Câmara], tenta enrolar os deputados [em relação às denúncias que o envolvem], mas vê suas mentiras cair por terra em tempo recorde".

Nesse sentido, o texto exerce uma função de ancoragem em relação à imagem. Na medida em que oferece informações que explicam, de maneira resumida, o motivo de tal político estar sendo assim representado, ele a justifica e a valida. As expressões "mestre dos disfarces", "tenta enrolar" e "suas mentiras" são centrais para esse entendimento. Outro título, do box que ocupa a parte inferior das duas páginas da matéria, cumpre a mesma função, de modo mais direto: "O deputado Pinóquio: as declarações do ex-ministro José Dirceu, feitas no depoimento dado na 
terça-feira passada ao Conselho de Ética da Câmara dos Deputados, não se sustentaram por mais do que algumas horas". A identificação de Dirceu como um "deputado Pinóquio" fixa de vez o significado visualmente construído.

No decorrer da matéria, é dado suporte a esse sentido. Mais do que isso, ele parece tentar despertar valores morais e ideológicos do receptor. Promovendo a assimilação do político através de suas mentiras e envolvendo a premissa de que faltar à verdade é errado de acordo com os padrões éticos vigentes, a informação arquitetada, visualmente e verbalmente, refere-se a uma interpretação dos fatos que coloca Dirceu na posição de um contador de lorotas que deve ser por isso recriminado.

Assim, o resultado de tal foto-ilustração parece basear-se não tanto no fato de a imagem assemelhar-se a Dirceu ou ser uma fotografia efetiva do deputado, mas, sim, na evocação de uma predisposição a encontrar equivalências que assegurem a coerência do significado transmitido pela representação: reage-se a foto-ilustração como se ela fosse uma figuração do verdadeiro caráter do retratado. Nesse ponto, a distorção da imagem torna-se real. Ao mostrar um indivíduo apropriadamente caricaturado, a ilustração fotográfica transforma-o aos olhos do receptor, que passa a vê-lo a partir das características a ele atribuídas - como na boa caricatura. (KRIS; GOMBRICH, 1938).

Isso se dá também no que concerne às foto-ilustrações em que, ao invés de satirizar um indivíduo em específico, toma-se uma situação como alvo das críticas e censuras, como "A second life do petismo" (Figura 3).

Embora seja considerada uma ilustração fotográfica, essa imagem faz uso subsidiário da fotografia, servindo apenas para dar rosto às personagens que nela aparecem, os políticos José Dirceu, Ciro Gomes, Lula e José Genuíno. Com exceção dos semblantes desses sujeitos, a representação baseia-se, primordialmente, em um desenho, no qual eles aparecem sobrepostos a corpos desenhados que preenchem um cenário irreal. 


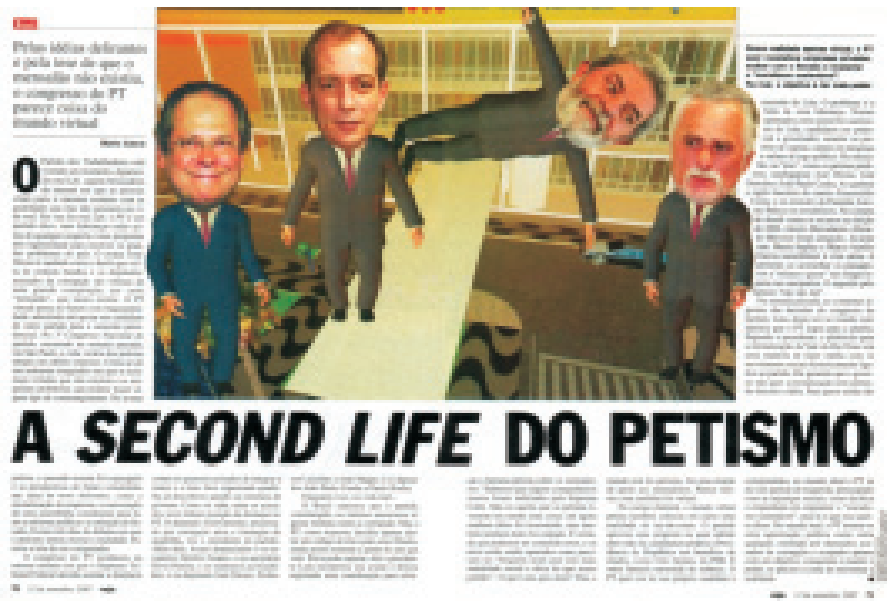

Figura 3 - Montagem da revista Veja

Fotografia: Agliberto Lima, Paulo Liebert, Ricardo Stuckert e Ed Ferreira Fonte: Veja de 12 de setembro de 2007, p.70-71

Nele, tem-se uma construção arquitetônica e quatro sujeitos, organizados numa composição que não respeita quaisquer princípios de realismo: os planos surgem sob ângulos distintos, falta perspectiva aos indivíduos, as cabeças aparecem desproporcionais aos corpos e as pessoas assumem disposições impossíveis. Cria-se, portanto, uma ambientação surreal que, tão cheia de disjuntores, se afasta da representação figurativa para estabelecer-se como uma paródia da realidade.

No topo da imagem, outro elemento aparece sutilmente, mas de modo a direcionar a leitura. Trata-se de uma lista azul que é culturalmente identificada como a barra de título típica a programas de computador. Todas essas unidades visuais, assim construídas, levam o receptor a associar a representação a uma realidade virtual, que serve como chave para a interpretação da paródia que se executa por meio dela. $\mathrm{O}$ seu significado se faz completo por meio dos textos que a acompanham.

O título da matéria soluciona em poucas palavras o entendimento da foto-ilustração. "A second life do petismo" é categórico ao fixar seu sentido: "o Partido dos Trabalhadores está vivendo um momento, digamos, Second Life, aquela brincadeira da internet em que as pessoas criam para 
si mesmas avatares com as qualidades que elas não possuem na vida real", como diz o texto da reportagem.

O significado visualmente modelado, de uma realidade virtual, é confirmado. O subtítulo vai além e explicita a justificativa de tal afirmação ao expor que é "pelas idéias delirantes e pela tese de que o mensalão não existiu que o congresso do PT parece coisa do mundo virtual". O mesmo papel exerce a legenda da imagem: "Numa realidade apenas virtual, o PT quer reestatizar empresas privadas, acabar com o Senado e implantar o 'socialismo sustentável'. Na real, o objeto é ter mais poder".

Na matéria, esse sentido é não apenas confirmado, mas também melhor posicionado. Se a representação, a princípio, parece pôr-se como uma paródia da realidade, a reportagem deixa claro que, efetivamente, a realidade tem sido parodiada pelo próprio governo. $\mathrm{O}$ texto e a imagem, integrados, funcionam para transmitir esse julgamento de que o PT "reinventa a realidade", numa conotação claramente irônica, satírica. Nesse ponto, igualmente, a distorção da imagem tornase real.

Esse aspecto último de sátira é um dado constante nas fotoilustrações de efeito cômico - parecendo confirmar, no que diz respeito a essas imagens, o juízo de Propp segundo o qual a zombaria é o único elemento permanentemente ligado ao humor. A ilustração fotográfica toma, então, os ares de "comentários sociais velados pela ironia ou explicitamente opinativos pela sátira e pelo sarcasmo". (FONSECA, 1999, p.13). A exageração, a justaposição não usual e as relações irônicas, empregadas de modo fantasioso ou lúdico em um sentido de incongruência, são os principais recursos utilizados. É a partir deles, ao expressar conteúdos analíticos e opinativos através do apontamento satírico, que a foto-ilustração parece exigir daqueles que a tomam para leitura um julgamento de crítica ou censura, reforçando sua dimensão de "arma". 


\section{O caráter metafórico}

Entre as estratégias das quais a ilustração fotográfica faz, o metaforismo é outra que se destaca. Faz-se necessário, pois, partir para o entendimento do que seja metáfora e de como ela opera nesses casos específicos. Não se pretende, com isso, esgotar as definições de metáfora - objeto de estudos de uma longa tradição filosófica e linguística. Entretanto, é preciso tecer algumas considerações sobre ela para auxiliar no entendimento do caráter metafórico da foto-ilustração.

De acordo com uma das primeiras definições dadas ao termo, metáfora é toda e qualquer aplicação do nome de uma coisa à outra, podendo ocorrer entre gêneros, espécies ou por simples analogia ${ }^{5}$. (ARISTÓTELES, 2004). Nessa acepção, percebida como uma espécie de refinamento através da substituição de uma palavra usual por uma mais incomum, ela serve a fins decorativos, com vista a efeitos poéticos e/ou retóricos.

Posteriormente, alguns autores começaram a conceber o recurso metafórico para além dessa finalidade, apreendendo-o também como um fenômeno cognitivo a partir do qual é possível gerar uma melhor compreensão da realidade. Isso se faz possível na medida em que a ideia de metáfora enquanto substituição nominal é superada pela noção de interação. Por metáfora denomina-se a co-relação estabelecida entre duas coisas (ou sistemas) em que a segunda projeta sobre a primeira uma série de características e implicações associadas que funciona como mediadora de uma analogia ou correspondência estrutural que se faz possível entre elas. (BLACK, 1993).

\footnotetext{
${ }^{5}$ Essa definição engloba nos limites da metáfora outras figuras retóricas, a exemplo da sinédoque e metonímia (entendidas como espécies de metáforas). As definições que se seguiram a essa, no entanto, costumam explicar cada uma dessas figuras separadamente. Embora as três sejam caracterizadas como substituição de um termo por outro, a relação estabelecida entre os termos é diferenciada em cada caso: na metáfora, a relação se dá por analogia; na sinédoque, por extensão (parte pelo todo, espécie pelo gênero, singular pelo plural etc.); e na metonímia, por contiguidade (causa pelo efeito, continente pelo conteúdo etc.).
} 
Em tal sentido, ao associar propriedades de um sistema ao outro, "a essência da metáfora é compreender e experenciar um tipo de coisa em termos de outro". ${ }^{6}$ (LAKOFF; JOHNSON, 1980, p.5). Passase, pois, a idealizar a metáfora como uma forma de estruturação do conhecimento de uma coisa em função do de outra: ao transferir propriedades de uma para a outra, permite-se a compreensão da primeira através do que se sabe sobre a segunda, estabelecendo-a a partir de uma nova maneira de interpretação.

Segundo essa perspectiva, o metaforismo não se realiza apenas no nível nominal, como se propôs primordialmente. A teoria da metáfora conceitual, proposta com George Lakoff e Mark Johnson, avança no sentido de afirmar que a metáfora é, por definição, a compreensão de um domínio conceitual através de outro, mais familiar ou acessível. Assim sendo, a base do recurso metafórico se situa fundamentalmente ao nível conceitual, sendo a projeção de características de um nome para outro apenas uma das manifestações possíveis desses conceitos metafóricos.

Abre-se, assim, a possibilidade de conceber a existência de metáforas visuais como expressão de um conceito metafórico que subjaz e ganha forma na representação.

A definição da metáfora visual em termos de um conceito subjacente é consistente com os princípios fundamentais da teoria conceitual da metáfora, que é o paradigma corrente nesse campo de estudos. Tal definição cognitiva me parece ser uma boa base na qual é possível começar a entender a natureza da metáfora visual. Ela não apenas amplia consideravelmente o escopo do que pode ser considerado metáfora visual, possibilitando explorarse as várias formas que ela pode assumir nos gêneros visuais, como também torna mais fácil o estabelecimento de comparações entre as formas verbais e visuais de expressar o mesmo conceito metafórico. ${ }^{7}$ (EL REFAIE, 2003, p.81).

\footnotetext{
${ }^{6}$ Tradução livre da autora.

${ }^{7}$ Tradução livre da autora.
} 
Pensando as foto-ilustrações por essa perspectiva, percebe-se a recorrência desse recurso. Por exemplo, as relações instituídas entre os empresários e santos (Figura 1), entre o político e Pinóquio (Figura 2) e entre a realidade e um jogo virtual (Figura 3 ) funcionam como paralelo de um conceito metafórico subentendo, a partir do qual é possível projetar atributos de um sistema ao outro, predicando os primeiros com as características normalmente conferidas aos segundos - indicando associações a partir das quais é possível fazer compreensível o argumento que está sendo estabelecido.

Para tanto, a metáfora funciona sempre por meio da comparação entre sistemas distintos que se assemelham em algum aspecto. É através da explicitação dessa semelhança, ao fazer analogia entre as qualidades dos sistemas relacionados, que esse conceito metafórico se manifesta. É o que acontece em "O grande Natal de Lula" (Figura 4).

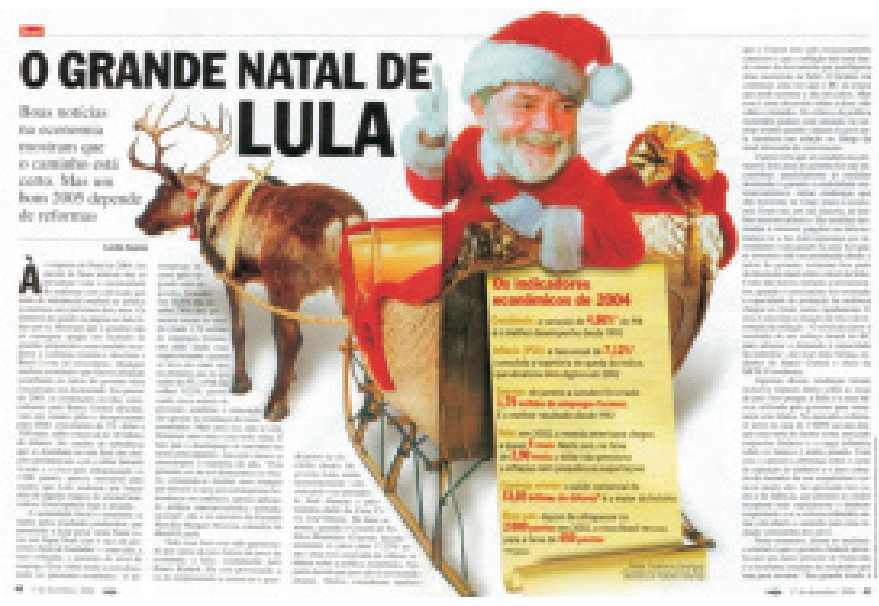

Figura 4 - Montagem da revista Veja Fotografia: Stock Photos e Alan Marques

Fonte: Veja de $1^{\circ}$ de dezembro de 2004, p.40-41

Essa ilustração fotográfica consiste, obviamente, numa montagem. Através da combinação de fotografias diferentes, obtém-se uma imagem improvável ou inusitada, na qual o presidente do país é visto usando trajes 
de Papai Noel, num trenó puxado por uma rena. Entretanto, percebida como montagem, a foto-ilustração não tenta enganar ou fazer crer naquilo que não é: o surgimento de sentidos que vão além do que é disposto na representação justifica o seu emprego.

Assim, o verdadeiro sentido dessa ilustração fotográfica só pode ser captado quando, ao fazer uma leitura imediata da mensagem, constatase uma impertinência em seu conteúdo. Se nenhuma significação pertinente advém da literalidade do que é percebido na imagem, o receptor é levado a recusá-la em favor de uma apreensão figurativa. Parte-se, então, para um trabalho interpretativo que consiste em inferir um código que torne a fotografia aceitável, dissolvendo a falsidade ou a falta de sentido que pode lhe ser conferido ao primeiro olhar - como acontece na interpretação das diferentes manifestações da metáfora.

Realiza-se um apaixonante vaivém hermenêutico: pressupõe-se um código, que é verificado na comparação, saboreando antecipadamente suas transformações metafóricas; parte-se da comparação para inferir um código que a torne aceitável [...]. Analisando melhor este processo por tentativa e erro percebemos que estamos diante de múltiplos movimentos inferenciais: hipótese (ou abdução), indução, dedução. (ECO, 1991, p.162).

A partir desse processo dedutivo, estabelece-se uma analogia ou correspondência estrutural entre Lula e Papai Noel. O sentido evocado nessa foto-ilustração passa, pois, por um entendimento metafórico que transfere propriedades de uma coisa à outra. Papai Noel, personagem associada à benevolência, à generosidade e ao altruísmo, empresta ao presidente tais características que lhes são próprias.

Auxiliada pelos elementos verbais de maior destaque na página ("O grande Natal de Lula", título da matéria, e "Os indicadores econômicos de 2004", título do box que a acompanha), a imagem constrói visualmente um significado que reforça a análise apresentada pelo texto: os bons índices econômicos, que faz o Brasil prosperar, permitem "a Lula posar neste Natal como um Papai Noel com o saco de presentes cheios de bondades". 
Dessa forma, ao representar Lula assim, associando-o a Papai Noel, possibilita-se a compreensão da situação econômica por meio de termos que são mais familiares ao receptor, relacionados à ideia de Natal. Nessa ocorrência, o sentido que quer ser dado à representação passa pela configuração de um fato ou acontecimento de modos a serem mais facilmente apreendidos através da comparação - verbal e visual.

O mesmo acontece em "Referendo da fumaça" (Figura 5), ilustração fotográfica na qual um homem aparece apontando para si mesmo uma arma que é formada a partir do seu próprio dedo.

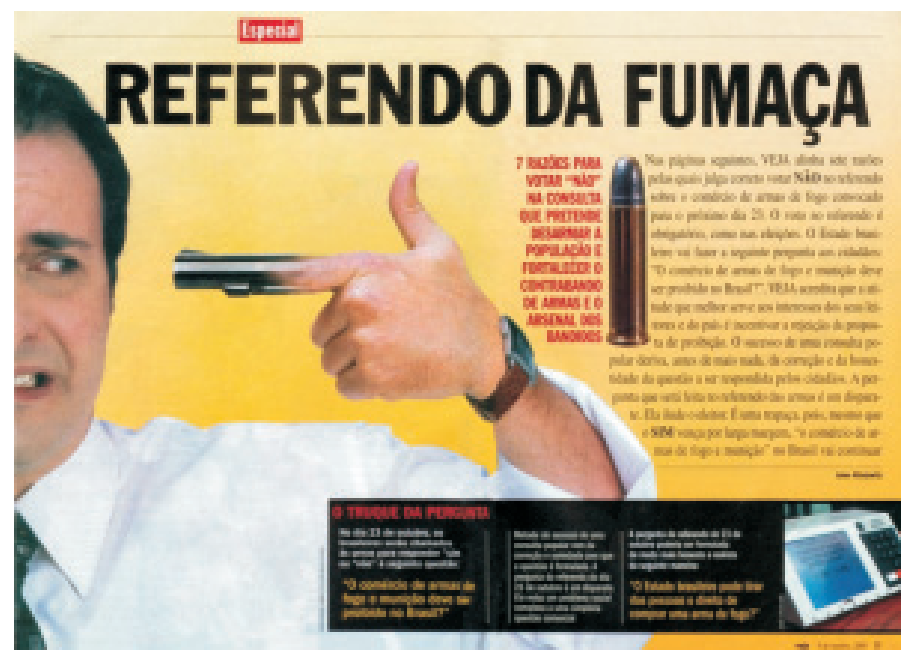

Figura 5 - Montagem revista Veja

Fotografia: Paulo Vitale

Fonte: Veja de 5 de outubro de 2005, p.76-77

No centro da fotografia e sem outros elementos que concorram em atenção, a mão do sujeito se firma como unidade visual principal. A posição em que ela é fotografada, com o punho fechado, polegar para cima e o indicador como se mirasse um alvo, não é fortuita. Culturalmente codificado como sendo a representação de um revólver, esse gesto reveste-se de uma dimensão convencional, funcionando como símbolo de uma arma. Porém, a constituição da mão como arma não para por aí. Transmutado 
através da mesclagem de imagens, o dedo indicador é efetivamente substituído pelo cano de um revólver.

Assim, a foto-ilustração estabelece seu primeiro significado: temse, então, que o indivíduo aponta para si mesmo uma arma que é, na verdade, o seu próprio dedo. A imagem, assim construída, expressa um pensamento metafórico que ganha forma na representação, equivalente visual da metáfora "a mão do homem é uma arma".

A interpretação dessa metáfora não para por aí, posto que a ilustração fotográfica evoca outros elementos para completar seu sentido. O fundo da composição, por exemplo, destaca-se como elemento icônico importante. Em amarelo, ele desperta um repertório cultural que associa essa cor a valores como de atenção e cautela, imprimindo um estado de alerta à representação. Visualmente, constrói-se um sentimento de perigo, ponto comum entre os componentes da imagem que se convertem em expectativa para a resolução da metáfora da "mão-revólver".

O rosto do homem, que aparece como alvo, é um desses componentes. A testa franzida, a sobrancelha e os olhos apertados, a boca entreaberta e os dentes cerrados estampam nele uma fisionomia transtornada, um ar de perturbação e desespero. Olhando para a "mãorevólver", ele exibe-a como explicação para o seu transtorno, como se a sua expressão fisionômica fosse uma consequência da percepção de que sua própria mão foi convertida numa arma da qual agora ele mesmo é vítima. Uma segunda metáfora toma forma: "o cidadão é vítima".

A partir dessas duas analogias ou correspondências estruturais estabelecidas, há a projeção dos campos semânticos associados a "arma" e a "vítima", segundos sistemas da metáfora, que permitem entender os primeiros de acordo com eles - principalmente, da noção de perigo.

Entretanto, por si sós, essas metáforas não arrematam o significado da foto-ilustração. Os elementos verbais complementam-no. O título da matéria, disposto logo no topo da composição, ajuda na contextualização da imagem ao coligá-la a um assunto então em pauta, o referendo sobre o comércio de armas de fogo. O subtítulo "7 razões para votar 'não' na consulta que pretende desarmar a população e fortalecer o contrabando 
de armas e o arsenal dos bandidos" vai além. Ele não apenas confirma o título na referência ao fato do qual trata, como demarca o posicionamento que a revista assume. Sabe-se, assim, que a reportagem sustenta uma opinião contrária à proposta de proibição da comercialização de armas.

Nesse ponto, o significado da fotografia se completa. Ao coligar-se ao texto, que a ancora, ela implicitamente comunica a ideia de que está nas mãos do cidadão decidir o resultado e as consequências do referendo. É interessante notar que o dedo transmutado, o indicador, é exatamente aquele usado para apertar o "sim" ou o "não" da urna eletrônica. Se ele pode ser uma arma, a reportagem aconselha as pessoas a usá-la ao seu favor. Ao cidadão compete o poder de votar contra, de maneira a impedir que aquilo que é metaforicamente demonstrado na foto se concretize, isto é, que ele se torne vítima de si mesmo. A imagem funciona como uma espécie de alerta a dizer "cuidado, a maior vítima é você".

Todos esses significados que surgem a partir de tal ilustração fotográfica são possíveis pelos conceitos metafóricos nela literalizados ${ }^{8}$, que ajuda a explicar a votação através de noções agregadas com as ideias de "arma" e "vítima". Não se trata, portanto, de uma apresentação ou descrição neutra do assunto noticiado, mas reflete uma opinião sobre ele. Há, portanto, o estabelecimento de uma determinada percepção ideológica da realidade que se retrata. Ao entrar em contato com a foto-ilustração, o espectador igualmente a compreende e a experiencia assim.

\section{Considerações finais}

Como aqui delineadas, a comicidade e a metáfora são estratégias de construção de sentidos da ilustração fotográfica mobilizadas a fim de, por um lado, estabelecer uma relação de cumplicidade ou simpatia com o

\footnotetext{
${ }^{8}$ Ainda que a relação mão-arma e cidadão-vítima possa ser pensada enquanto contiguidade, tipificando uma metonímia, essa imagem é classificada como metafórica em função da ideia de um conceito metafórico subjacente, que explica uma coisa em termos de outra.
} 
seu público e, por outro, contribuir com a ficção em seu papel de operador cognitivo. Nesses casos, elas funcionam para um fim retórico: configuramse como procedimentos para a construção de uma mensagem que visa guiar o leitor na interpretação dos assuntos noticiados, de acordo com o que é sugerido no texto.

Assim, a foto-ilustração acaba funcionando como um auxílio visual para melhor expressar determinadas ideias e pontos de vista por eles defendidos. Conectada ao texto, complementando o discurso verbal e sendo por ele complementada, ela é capaz de tornar mais compreensível e convincente aquilo que se comunica.

É nesse ponto que a ilustração fotográfica se delineia como imagem de uso jornalístico. Na condição de ilustração, mais do que simplesmente exercer um papel de mero coadjuvante, ornamento ou enfeite do texto verbal, esse tipo de fotografia ajuda a construir um conceito que metaforicamente explica o que está sendo esclarecido pela reportagem; afirmando-se, então, como forma expressiva com características e contribuições específicas para a atividade jornalística, em especial para o jornalismo empreendido pelas revistas de informação.

\section{Referências}

ARISTÓTELES. Poética. Lisboa: Fundação Calouste Gulbenkian, 2004.

BAEZA, Pepe. "Invocación y modelo: las nuevas imágenes de la prensa". In: Anàlise: quaderns de comunicació i cultura, n. 27.

Barcelona: Universitat Autònoma de Barcelona, 2001. Disponível em: $<$ http://ddd.uab.cat/pub/analisi/02112175n27p159.pdf $>$. Acesso em: 8 mai. 2008.

BARTHES, Roland. A câmera clara: nota sobre a fotografia. Rio de Janeiro: Nova Fronteira, 1998. 
BENETTI, Marcia. A ironia como estratégia discursiva da revista Veja. In: XVI Encontro da Compós - Anais. Curitiba: Associação Nacional dos Programas de Pós-Graduação em Comunicação, 2007.

BERGSON, Henri. O riso: ensaio sobre a significação do cômico. Rio de Janeiro: Zahar, 1983.

BLACK, Max. More about metaphor. In: ORTONY, Andrew. Metaphor and thought. Cambridge: Cambridge University Press, 1993.

ECO, Umberto. Semiótica e filosofia da linguagem. São Paulo: Ática, 1991.

EL REFAIE, Elisabeth. Understanding visual metaphor: the example of newspaper cartoons. Visual communication, vol.2, n.1, 2003. Disponível em: $<$ http://visculture.files.wordpress.com/2007/02/ understanding-visual-metaphor.pdf $>$. Acesso em: 10 jun. 2008.

ERMIDA, Isabel Cristina. Humor, linguagem e narrativa: para uma análise do discurso literário humorístico. Braga: Universidade do Minho, 2002. Disponível em: $<$ https://repositorium.sdum.uminho.pt/handle/ 1822/190?mode=full $>$. Acesso em: 22 abr. 2008.

FONSECA, Joaquim. Caricatura: a imagem gráfica do humor. Porto Alegre: Artes e Ofícios, 1999.

GOMBRICH, Ernst. Arte e ilusão: um estudo da representação pictórica. São Paulo: Martins Fontes, 2007.

GOMES, Wilson. Princípios de poética (com ênfase na poética do cinema). In: PEREIA, Miguel; GOMES, Renato; FIGUEIREDO, Vera Lúcia (Orgs.). Comunicação, representação e práticas sociais. Rio de Janeiro: Editora PUC, 2004. 
HELLER, Steven. Design humor: the art of graphic wit. New York: Allworth Press, 2002.

KELLY, James; NACE, Diona. "Credibility of digital newsphotos". In: Association for education in journalism and mass communication. Kansas City: AEJMC, 1993.

KRIS, Ernst; GOMBRICH, Ernst. The principles of caricature. British Journal of Medical Psychology, vol. 17, 1938. Disponível em: $<$ http://www.gom brich.co.uk/show doc.php?id=85>. Acesso em: 27 jan. 2008.

LAKOFF, George; JOHNSON, Mark. Metaphors we live by. Chicago: University of Chigaco Press, 1980.

MORIN, Violette. A historieta cômica. In: BARTHES, Roland (Org.). Análise estrutural da narrativa. Petrópolis: Vozes, 1973.

MOTTA, Luiz Gonzaga. O jogo de intencionalidades e reconhecimentos: pragmática jornalística e construção de sentidos. Comunicação e espaço público, ano VI, n. 1 e 2. Brasília: UnB, 2003.

PROPP, Vladimir. Comicidade e riso. São Paulo: Ática, 1992.

SCALZO, Marília. Jornalismo de revista. São Paulo: Contexto, 2004.

SOUSA, Jorge Pedro. Uma história crítica do fotojornalismo ocidental. Florianópolis: Letras Contemporâneas, 2000.

SOUSA, Jorge Pedro. Fotojornalismo: introdução à história, às técnicas e à linguagem da fotografia na imprensa. Florianópolis: Letras Contemporâneas, 2004. 